\title{
Evaluasi Pelaksanaan Program Pemberdayaan Ekonomi Masyarakat Pesisir (PEMP) Sebagai Upaya Penanggulangan Kemiskinan di Kecamatan Batudaa Pantai Kabupaten Gorontalo
}

\author{
Harson Gasim \\ Widyaiswara Ahli Madya Badan Kepegawaian Pendidikan dan Pelatihan Daerah Provinsi \\ Gorontalo,Indonesia \\ Email: harsonlamu@yahoo.co.id
}

\begin{abstract}
The potential of marine resources that is large enough owned by Gorontalo Regency in reality has not been able to give maximum contribution for improving coastal community welfare. The most dominant issue facing coastal areas is the problem of poverty. The purpose of this study is to find out how far the impact of this PEMP program on poverty alleviation in District Batudaa Pantai Gorontalo. The type of this study is an evaluative study. The type of evaluation study used is a descriptive evaluation of assessing and analyzing data by describing or describing existing data and analyzing the results. The results show that the KMP selection mechanism has not yet given room for participation in decision-making and empowerment of the poor; Disbursement mechanism and fund management less effective, not transparent; Strengthening of socio-economic organization of society not yet effective and process of assistance less than optimal
\end{abstract}

Keywords: Evaluation; Program; Policy, Empowerment.

\begin{abstract}
Abstrak
Potensi sumber daya laut yang cukup besar yang dimiliki Kabupaten Gorontalo dalam kenyataannya belum mampu memberikan kontribusi secara maksimal bagi peningkatan kesejahteraan masyarakat pesisir. Persoalan yang paling dominan yang dihadapi wilayah pesisir justru masalah kemiskinan. Tujuan penelitian ini ialah untuk mengetahui seberapa jauh dampak program PEMP ini terhadap penanggulangan kemiskinan di Kecamatan Batudaa Pantai Kabupaten Gorontalo. Adapun tipe penelitian ini merupakan suatu studi evaluatif. Jenis studi evaluasi yang digunakan adalah evaluasi deskriftif yaitu menilai dan menganalisa data dengan cara menggambarkan atau mendeskripsikan data yang telah ada dan menganalisanya Hasil penelitian menunjukkan Mekanisme pemilihan KMP belumlah memberi ruang partisipasi dalam pengambilan keputusan dan pemberdayaan masyarakat miskin; Mekanisme pencairan dan pengelolaan dana kurang efektif, tidak transparan; Penguatan organisasi sosial ekonomi masyarakat belum efektif serta proses pendampingan kurang optimal
\end{abstract}

Kata Kunci: Evaluasi; Program; Kebijakan; Pemberdayaan 


\section{PENDAHULUAN}

Potensi sumber daya laut yang cukup besar yang dimiliki Kabupaten Gorontalo dalam kenyataannya belum mampu memberikan kontribusi secara maksimal bagi peningkatan kesejahteraan masyarakat pesisir. Persoalan yang paling dominan yang dihadapi wilayah pesisir justru masalah kemiskinan.

Pada saat ini, di Kabupaten Gorontalo terdapat sekitar 5.634 jiwa nelayan beserta keluarganya yang berada pada 59 desa pesisir di daerah ini atau $1.39 \%$ dari total jumlah penduduk 404.820 jiwa (LEPP-M3 Payulimo, 2002). Dari jumlah 5.634 jiwa nelayan ini, 1.974 jiwa atau $35.04 \%$ berada di Kecamatan Batudaa Pantai (Biro Sosial Setda Kab.Gorontalo, 2004) yang sebagian besar merupakan penduduk miskin. Padahal Kecamatan Batudaa Pantai wilayahnya berada dan berbatasan langsung dengan Perairan Teluk Tomini (Teluk Gorontalo) yang memiliki kekayaan hayati yang terlengkap di dunia (beraneka ragam) (Presnas Publising, 2002) dengan potensi sumber daya alam kelautan dan perikanan tangkap yang melimpah.

$\begin{array}{rcr}\quad \text { Berbagai } & \text { program } & \text { telah } \\ \text { dilaksanakan } & \text { dalam } & \text { rangka } \\ \text { menanggulangi } & \text { kemiskinan } & \text { masyarakat }\end{array}$ pesisir di Kecamatan Batudaa Pantai, misalnya IDT, KUT, PPK, dan program aksi lainnya, tetapi pada evaluasi akhir, hasilnya kurang sesuai dengan harapan dan jauh dari sasaran.

Belajar dari kegagalan dari berbagai program di atas maka pada Tahun Anggaran 2002, Pemerintah Daerah Kabupaten Gorontalo melaksanakan program Pemberdayaan Ekonomi
Masyarakat Pesisir (PEMP), dengan mengalokasikan dana dampingan melalui sistem avalis Bupati Gorontalo, sematamata diharapkan guna peningkatan kesejahteraan masyarakat pesisir yang selama ini sering terpinggirkan.

Melalui program PEMP, kepada 9 desa dari 12 desa di kecamatan Batudaa Pantai yaitu Desa Huwongo, Biluhu Barat, Lobuto, Luluo, Biluhu Tengah, Lamu, Tontayuo, Biluhu Timur dan Desa Lopo, disalurkan sejumlah dana yang diavalis dengan dana PEMDA Kabupaten Gorontalo.

Mengingat bahwa pada saat ini program PEMP telah dinyatakan selesai pelaksanaannya, maka perlu di evaluasi guna mengetahui seberapa jauh dampaknya terhadap penanggulangan kemiskinan di Kecamatan Batudaa Pantai Kabupaten Gorontalo.

\section{METODE PENELITIAN}

Adapun tipe penelitian ini pada dasarnya adalah merupakan suatu studi evaluatif. Jenis studi evaluasi yang digunakan adalah evaluasi deskriftif yaitu menilai dan menganalisa data dengan cara menggambarkan atau mendeskripsikan data yang telah ada dan menganalisanya untuk mendapatkan gambaran umum. Peneliti bukan saja memberikan gambaran fenomena-fenomena, tetapi juga mungkin membuat prediksi serta mendapatkan makna dan implikasi dari suatu masalah yang ingin dipecahkan (Gunawan Sumodinigrat, 2010).

Sesuai dengan tujuan dan kebutuhan analisis, maka populasi dalam penelitian ini adalah semua anggota kelompok masyarakat pemanfaat (KMP) program PEMP di Kecamatan Batudaa Pantai. 
Sedangkan yang menjadi sampel dalam penelitian ini adalah Kelompok Masyarakat Pemanfaat Sinar Desa Lamu yang beranggotakan 20 Kepala Keluarga, dan Kelompok Masyarakat Pemanfaat Starmon Desa Tontayuo juga beranggotakan 20 Kepala Keluarga. Dengan demikian, responden penelitian ini.

Dalam rangka memperoleh data dan informasi yang lengkap dan memadai, maka peneliti akan menggunakan teknik pengumpulan data sebabagi berikut :

1. Observasi. Teknik pengumpulan data yang dilakukan melalui pengamatan langsung terhadap fenomena sosial yang tampak pada obyek penelitian pada tempat dinama suatu kebijakan atau program (PEMP) pernah dilaksanakan.

2. Wawancara. Dilakukan terhadap imporman yang telah ditetapkan ditetapkan antara : 1) Unsur penanggung jawab proyek yaitu Kadis/Wakadis Dinas Perikanan dan Kelautan Kabupaten Gorontalo (pejabat yang berkompotensi lainnya), Ketua Team Leader Konsultan Manajemen, Ketua Pengurus LEPP-M3, Camat Batudaa Pantai dan Para pengurus KMP, para Kepala Desa dan Tokoh Masyarakat di Kecamatan maupun di Desa masing-masing lokasi penelitian.

3. Dokumentasi. Teknik dilakuakan dalam rangka mendapatkan data sekunder, diperoleh melalui penelusuran terhadap dokumen-dokumen, literatur-literatur dan laporan-laporan serta arsip-arsip pada kantor terkait yang berhubungan dengan program PEMP seperti kantor Konsultan Manajemen, Kantor LEPPM3, dan Dinas Perikanan dan Kelautan. Karena dalam banyak kasus, penelitian harus lebih mengandalkan dokumentasi daripada survei, karena data dokumentasi mengatasi kendala ruang dan waktu suatu penelitian (Riswandha Imawan, 2004).

Untuk data hasil wawancara dari suatu sumber data dicorss-checkkan dengan hasil wawancara dari sumber data lain. Dari sini dapat diketahui ada-tidaknya perbedaan pendapat, pandangan atau pemikiran tentang suatu obyek diantara sumber data tersebut.

Demikian juga dengan data dukumen-dokumen yang ada di tingkat aparat dan organisasi dicrosscheckkan dengan dokumen-dokumen dan fakta yang ada pada sumber lain dan hasil wawancara dengan responden. Sedangkan analisis data yang bersifat kuantitatif akan dilakukan dengan menggunakan analisis tabel frekwensi dan cross-tabulasi.

\section{HASIL DAN PEMBAHASAN}

\section{Kemiskinan Masyarakat Pesisir}

Sunyoto Usman (2004:127-129) mengemukakan sedikitnya ada dua macam perspektif yang lazim dipergunakan untuk mendekati kemiskinan, yaitu perspektif kultural dan perspektif struktural. Perspektif kultural mendekati kemiskinan pada tingkat analisis: individual, keluarga dan masyarakat. Pada tingkat individual ditandai dengan sifat paroial, apatisme, fatalisme atau pasrah pada nasib, boros, tergantung dan inferior. Pada tingkat keluarga ditandai dengan anggota keluarga yang besar dan pada tingkat masyarakat ditandai dengan tidak terintegrasinya masyarakat dengan instutsi-institusi masyarakat secara efektif. Sedangkan menurut perspektif struktural, kemiskinan merupakan dampak dari sistem ekonomi 
yang mengutamakan akumulasi kapital dan produk-produk teknologi modern sehingga hanya mengutamakan pertumbuhan dan kurang memperhatikan pemerataan hasil pembangunan.

Berdasarkan defenisi diatas, bahwa karakteristik kemiskinan yang muncul dan dialami oleh masyarakat pesisir di kecamatan Batudaa Pantai Kabupaten Gorontalo merupakan akumulasi antara persfektif kultural (sosio-budaya) dan persfektif struktural. Hal ini dapat dirumuskan (1) adanya kelompok anggota masyarakat yang secara struktur tidak mempunyai kemampuan yang memadai untuk mencapai tingkat kehidupan yang memadai dan adanya kesenjangan akibat tidak mempunyai akses untuk menggunakan faktor produksi tertentu (2) adanya individual, keluarga dan masyarakat secara kultural memiliki budaya miskin ditandai dengan sifat paroial, apatisme, fatalisme atau pasrah pada nasib, boros, tergantung dan inferior. Pada tingkat keluarga ditandai dengan anggota keluarga yang besar dan pada tingkat masyarakat ditandai dengan tidak terintegrasinya masyarakat dengan instutsiinstitusi masyarakat secara efektif.

\section{Organisasi Sosial Ekonomi Masyarakat}

Max Weber (dalam Miftah Thoha, 2007) dalam pandangan klasiknya, mengemukakan bahwa suatu organisasi atau kelompok kerja sama mempunyai unsur-unsur antara lain : (1) merupakan tata hubungan sosial, dalam hal ini seorang individu melakukan proses interaksi sesamanya di dalam organisasi tersebut; (2) mempunyai batasan-batasan tertentu dengan demikian seseorang dapat melakukan hubungan interaksi dengan lainnya tidak atas kemauan sendiri; (3) merupakan kumpulan tata aturan yang membedakan dengan kumpulan-kumpulan kemasyarakatan. Tata aturan ini menyusun proses interaksi diantara orang yang bekerja sama di dalamnya, sehingga interaksi tersebut tidak timbul begitu saja; (4) merupakan suatu kerangka hubungan yang berstruktur yang didalamnya berisi wewenang, tanggungjawab, dan pembagian kerja untuk menjalankan sesuatu fungsi tertentu. Hierarki kewenangan seperti berkonsekuensi sebuah organisasi menghendaki ada pimpinan atau kepala dan bawahan atau staf.

Pendapat di atas menunjukkan bahwa organisasi merupakan suatu kelompok atau entitas sosial yang sadar bekerjasama secara terpadu dalam suatu konteks tertentu, menurut batas-batas dan fungsifungsi tertentu, guna mencapai suatu tujuan bersama tertentu atau suatu perangkat tujuan-tujuan bersama tertentu. Untuk dengan sadar dapat bekerjasama secara terpadu diperlukan manajemen. Untuk dapat merupakan suatu kelompok atau kesatuan sosial, maka orang-orang yang bersangkutan harus melakukan interaksi sosial. Interaksi sosial ini harus berlangsung secara seimbang dan serasi sehingga terjadilah suatu pola gerak yang terkoordinasikan. Bekerjasama untuk mencapai tujuan bersama yang tertentu berarti adanya suatu usaha, dan jika dilakukan dengan bentuk hukum ysng tertentu maka terjadilah suatu badan usaha. Dengan adanya batas-batas yang tertentu, maka dalam kelompok dapat diadakan pembagian kerja yang akan melahirkan tugas-tugas dan fungsi-fungsi. Selain itu, batas-batas organisasi tersebut dapat membedakan antara warga organisasi dan non warga organisasi. Dengan para warga organisasi dapat diadakan berbagai macam relasi/ikatan, misal kontrak sosial, kontrak 
manajemen, pelimpahan wewenang, penugasan, dan pertanggungjawaban, dan sebagainya.

\section{Evaluasi Dampak Program}

Langbein (1980), membagi studi evaluasi program menjadi dua pengertian, yakni : (1) Studi deskriptif, yaitu evaluasi program yang dilihat dari proses implementasi program tersebut sesuai dengan pedoman yang ada, sumber daya dan fasilitas apa saja yang digunakan dalam program tersebut serta bagaimana pemanfaatannya. Dari segi outcomes yang dipertanyakan adalah siapa saja yang terlibat dalam program. Apakah program telah menjangkau mereka yang dianggap sesuai dengan tuntutan mereka; (2) Studi kausal, mempertanyakan apakah suatu program atau proyek menghasilkan sesuatu dengan kebutuhan yang diinginkan, apabila implemntasi program atau proyek telah memperoleh hal yang terbaik.

Sehungan dengan penelitian, menggunakan jenis studi evaluasi bentuk pertama yaitu evaluasi deskriftif, yaitu akan berusaha mendapat gambaran umum tentang 4 aspek utama pelaksanaan program model PEMP yaitu mekanisme pemilihan KMPs, mekanisme pengelolaan dan pencairan dana, penguatan organisasi sosial ekonomi dan proses pendampingan. Apakah program PEMP dilaksanakan menurut pedoman? Fasilitas sumberdaya apa yang telah digunakan oleh program tersebut, sehingga diharapkan hasil dicapai memberi dampak pada masyarakat pesisir di Kecamatan Batudaa Pantai.

\section{Karakteristik Masyarakat Pesisir Di Kecamatan Batudaa Pantai}

Masyarakat pesisir Kecamatan Batudaa Pantai Kabupaten Gorontalo merupakan masyarakat nelayan (pelaut). Artinya laut begitu kuat melekat dan mempengaruhi interaksi keseharian mereka, sehingga apa pun profesi mereka, laut tetap menjadi sumber kehidupan baik langsung maupun tidak langsung. Melihat segi kejiwaannya sebagai nelayan, masyarakat pesisir Batudaa Pantai sulit dipisahkan dari laut. Dengan permainan perahu katir kecil (tradisional) tanpa mesin menerjang pecahnya ombak dipantai dan badai lautan yang ganas, tak membuat nyali menjadi ciut. Potensi kekuatan nyali mereka sebenarnya membentuk pribadi tegas sehingga mampu bertahan hidup dalam keadaan serba sulit (baca kemiskinan).

Dari segi pendidikan, masyarakat pesisir Batudaa Pantai memiliki tingkat pendidikan dan anak-anaknya rata-rata rendah menyebabkan sulitnya bagi anakanak mereka untuk mencari alternatif pekerjaan lain dan cenderung menurunkan pekerjaan orang tuanya sebagai nelayan. Selain itu mereka juga cenderung banyak anak dan dalam hal ini merupakan cerminan dari keinginan mereka agar anakanaknya ikut membantu dalam mencari nafkah.

Akibat rendahnya pendidikan dimiliki menyebabkan masyarakat pesisir. di Kecamatan Batudaa Pantai tidak dapat membayangkan pekerjaan lain yang lebih mudah sesuai dengan kemampuan yang mereka miliki. Keterampilan untuk menjadi nelayan bersifat amat sangat sederhana dan hampir sepenuhnya dapat dipelajari dari orang tua mereka maka sejak sejak mereka masih kanak-kanak. Oleh karena itu tidak mudah untuk beralih pekerjaan lain, sehingga terbiasa dengan pola penghasilan yang segera (instant) 
dimana penghasilan diperoleh setiap mereka pulang dari melaut. Boleh dikatakan hampir setiap hari bisa menghasilkan uang walaupun dengan jumlah yang tidak pasti.

Dari uraian di atas, pada prinsipnya menyatakan bahwa kondisi masyarakat pesisir di Kecamatan Batudaa Pantai sangat tergantung dari sumber daya yang dikuasai yaitu pesisir dan kelautan. Adanya keterkaitan yang sangat erat antara kualitas hidup mereka dengan sumber daya wilayah pesisir. Juga dapat digambarkan bahwa lingkungan wilayah pesisir Kecamatan Batudaa Pantai memiliki ciri-ciri permasalahan antara lain a) secara geografi terpencil; b) aksebilitas terbatas; c) ketergantungan terhadap sumber daya alam tinggi; d) ikatan kekerabatan kuat; e) pengetahuan kearifan masih kuat.

Selain beberapa hal diatas, masyarakat pesisir (nelayan) di Kecamatan Batudaa Pantai memiliki kemiripan dengan masyarakat petani. Misalnya, seperti usaha mereka berskala kecil dengan peralatan dan organisasi pasar yang sederhana. Eksploitasi sering terjadi berkaitan dengan masalah kerjasama dan sebagian besar dari mereka tergantung pada produksi yang bersifat subsisten serta memiliki keragaman dalam tingkat dan perilaku ekonomi.

\section{Stratifikasi Sosial Masyarakat Pesisir Batudaa Pantai}

Stratifikasi sosial atau pelapisan sosial adalah penggambaran kelompokkelompok dalam susunan yang hirarkis, berjenjang. Susunan hirarkis seperti itu muncul karena kehidupan manusia dilekati oleh nilai, yang tidak dimiliki oleh makhluk lain seperti misalnya terhina, diremehkan, ternista, manusia menyandang nilai tersebut. Keberadaan nilai itu selalu akan memberi harga pada penyandangnya, karena siapa yang memperoleh lebih banyak harga yang bernilai semakin terpandang bernilai tinggi dalam kehidupan kelompoknya, dan nilai ini tidak sama pada setiap masyarakat. Secara umum hal-hal yang mengandung nilai berkaitan dengan harga kekayaan, jenis mata pencaharian, pengetahuan/pendidikan , ketutrunan, keagamaan. Bagi masyarakat pesisir (nelayan) yang dipandang bernilai adalah pemilikan alat tangkap perikanan (modern). Maka seberapa besar pemilikan atau penguasaan seseorang terhadap peralatan tangkap perikanan akan menentukan kedudukannya mereka di tengah masyarakat.

Pengusaan dan pemilikan terhadap peralatan tangkap perikanan melahirkan struktur sosial di masyarakatnya pesisir Batudaa Pantai yaitu :

1. Nelayan kaya (juragan) yang terdiri dari : a) juragan yang memiliki kapal (pamo) sehingga mempekerjakan nelayan lain sebagai ABK tanpa ia sendiri harus bekerja; b) juragan yang memiliki kapal tetapi ia sendiri ikut bekerja sebagai anak kapal.

2. Nelayan sedang, yang kebutuhan hidupnya dapat ditutupi dengan pendapatan pokok dengan bekerja sebagai nelayan dan memiliki perahu tanpa mempekerjakan tenaga dari luar keluarganya;

3. Nelayan tradisonal miskin (bulotu) yang pendapatan tidak mencukupi kebutuhan hidupnya, sehingga ditambah dengan pekerjaan lain.

Jika diamati hirarki atau stratifikasi sosial di atas, maka untuk lokasi penelitian, tidak terdapat nelayan juragan atau 
nelayan kaya yang memiliki armada penangkapan ikan purse siene (pajeko). Hal ini menunjukkan bahwa sektor usaha perikanan tersebut tidak saja membutuhkan/padat modal tetapi juga dibutuhkan manejemen usaha yang mapan (modern) sementara nelayan di lokasi penelitian relatif berpendidikan rendah dan terbiasa dengan manejemen tradisonal/rumah tangga. Satu usaha purse siene (pajeko) merupakan sebuah kelompok nelayan yang anggotanya minimal 20 orang. Konsekuensi dari pengelompokan ini, akan berdampak pada kedudukan dalam kelompok misalnya : kapten/nahkoda, juru mesin, juru angin, juru masak, ABK, juru dorong. Kedudukan dan fungsi tersebut mempengaruhi pendapatan yang diperoleh. Semakin tinggi kedudukan seseorang dalam kelompok nelayan purse siene (pajeko) maka semakin besar pula pendapatan yang diterimanya.

Bila dilihat dari segi pembagian hasil, pada umumnya sistem bagi hasil pemilik modal (pejoko dan usaha lainnya) dengan nelayan ABK menggunakan sistem $50 \%$ untuk pemilik modal dan $50 \%$ untuk nelayan ABK. Dari $50 \%$ pembagian untuk nelayan ABK, akan dibagi lagi oleh anggotanya sesuai jumlah, peran dan kedudukan mereka dalam kelompok. Cara penghitungan hasil netto pendapatan sekali melaut adalah jumlah penjualan hasil tangkapan dikurangi dengan biaya operasi melaut. Dengan demikian, sistem pembagian hasil seperti ini, tetap saja yang diuntungkan adalah sepemilik modal sedangkan nelayan ABK tetap dalam posisi marginal.

Padatnya modal dan dibutuhkannya sistem manajemen perusahaan dalam mengelola usaha purse siene (pajeko) menjadi salah satu faktor, jenis usaha ini tidak dilakoni nelayan di lokasi penelitian. Disamping faktor tersebut, watak, nelayan tradisional di lokasi penelitian adalah nelayan tuna, dimana sistem operasional penangkapan ikan maupun manajemen usaha sangatlah sederhana.

Sratifikasi atau hirarki sosial nelayan yang paling kaya di lokasi penelitian adalah nelayan pemilik kapal/perahu (pamo) penangkap tuna, yang mempekerjakan ABK dan ada sebagian mereka bekerja sebagai ABK. Usaha penangkapan ikan tuna ini, maksimal dibutuhkan 5 sampai 8 nelayan dalam kelompok, dimana biasanya langsung dinahkodai oleh pemilik kapal/perahu.

Sehubungan penelitian yang dilakukan, maka fokus penelitian ini dilakukan terhadap nelayan tradisional miskin (buloto) atau nelayan penangkap tuna, mereka memiliki perahu dengan menggunakan layar dan dayun, pendidikan dan keterampilan relatif rendah, yang berdampak pada lemahnya dalam mengelola penghasilan, cenderung hanya berpikir untuk keperluan jangka pendek yaitu untuk sekedar mempertahankan hidup sehari-hari..

\section{Evaluasi Pelaksanaan Program Pemberdayaan Ekonomi Masyarakat Pesisir (PEMP)}

\section{Pemilihan Kelompok Masyarkat Pemanfaat (KMP)}

Hasil temuan di lapangan
menunjukkan mekanisme pemilihan anggota KMP "tidak melibatkan tokoh masyarakat, tetapi atas penunjukkan langsung Kepala Desa. Bahkan Sekretaris Desa pun tidak mengetahui siapa-siapa KK yang dipilih menjadi KMP. Dari 40 Respoden yang diajukan pertanyaan tentang aktor-aktor yang dilibatkan dalam penentuan dan pemilihan calon KMP 
sebanyak 38 anggota atau $95 \%$ menyatakan bahwa inisiatif pembentukan kelompok lebih banyak dari kepala desa, sedangkan sisanya 2 anggota $5 \%$ menyatakan melibatkan unsur masyarakat lainnya.

Menurut pengamatan, dari buku harian kelompok tentang catatan kegiatan sangat sedikit dan tidak teratur, hal ini menunjukkan bahwa pengurus kelompok tidak dapat menjalankan tugasnya sebagaimana mestinya. Hal tersebut di atas diperkuat dengan jawaban kuisioner, yaitu sebanyak 35 anggota 87,5\% menyatakan jarang sekali mereka membuat laporan kegiatan, hanya hal-hal tertentu saja, sedangkan 5 anggota atau 12,5 \% menjawab bahwa kalau setiap kegiatan selalu mereka buat catatannya.

Dari kedua data tentang mekanisme pemilihan angota KMP diuraikan di atas, pemilihan kurang dipersiapkan dan lemahnya pengetahuan anggota kelompok dalam mengadministrasi kegiatan kelompok menunjukkan bahwa kelompok ini dipilih dan dibentuk tanpa kriteria yang jelas. Hal ini diperkuat dengan jawaban respoden atas daftar pertanyaan, bahwa 37 responden atau 92,5\% menyatakan tidak mengetahui kriteria atau persyaratan untuk menjadi anggota KMP. Sedangkan 1 anggota atau 7,5 \% menyatakan mengetahui kriteria atau persyaratan untu menjadi anggota KMP.

Data-data di atas bila ditelaah, menunjukkan bahwa pemilihan dan pembentukan KMP pada program PEMP di Kecamatan Batudaa Pantai masih menggunakan pola lama yaitu masih bersifat top down walaupun esensinya adalah pemberdayaan masyarakat, tetapi tidak menyediakan mekanisme penyaluran aspirasi masyarakat sehingga penentuan kelompok sasaran yang miskin, masih menggunakan menggunakan kacamata dan standar pemerintah, sehingga kadang bantuan itu justru jatuh kepada yang tidak membutuhkan.

Kondisi ini menunjukkan dalam pembentukan KMP belum memberi peluang dan ruang bagi masyarakat untuk berpartisipasi dalam pengambilan dan penetapan keputusan. Padahal partisipasi dan peranserta mereka sangat urgen karena masyarakat lebih mengerti kondisi dan masalah yang sedang mereka hadapi.

\section{Pencairan dan Pengelolaan Dana}

Sumber dana program PEMP 2002 yang diberikan kepada Kekompok Masyarakat Pemanfaat yang ada di Kecamatan Batudaa Pantai Kabupaten Gorontalo berasal dari Program PEMP dan dana avalis/penjamin Pemerintah Daerah Kabupaten Gorontalo.

Mengenai sumber dana program PEMP, hasil pengamatan menunjukkan bahwa 40 responden atau $100 \%$ menyatakan bahwa dana tersebut berasal dari Bupati selaku Pemerintah Daerah Kabupaten Gorontalo, bahkan ada segelintir dari mereka mengatakan bahwa dana tersebut berasal dari bantuan partai Golkar. Keadaan di atas menunjukkan, kurang optimalnya sosialisasi yang dilakukan. Penjelasan yang benar, akan memberi pemahaman kepada masyarakat akan tujuan, maksud, dan aturan main pelaksanaan program. Jika dalam sosialisasi saja sudah tercipta opini bahwa dana ekonomi produktif bantuan merupakan Bupati, apalagi bantuan dari partai, maka akan semakin rendah tanggungjawab mereka dalam pengembalian pinjaman.

Dana bantuan ekonomi produktif program PEMP, yang diterima secara tunai oleh KMP hanya sebesar $10 \%$ dari 
keseluruhan dana, selebihnya dalam bentuk paket barang (dalam berita acara). Hasil konfirmasi dengan pihak Dinas Perikanan dan Kelautan Kabupaten Gorontalo tentang penyaluran bantuan dana ekonomi produktif kepada KMP tidak dalam bentuk uang tunai dengan alasan adanya khawatiran KMP tidak dapat menggunakan bantuan modal usaha dengan efektif. Oleh karena itu, atas kesepakatn dengan Team Konsultan dan LEPP-M3 untuk tidak memberikan dalam bentuk uang tunai tetapi dalam bentuk paket barang yang dibutuhkan KMP. Diakui bahwa kesepakatan ini tidak melibatkan KMP tetapi atas inisiatif kami.

Berdasarkan data yang ada, menunjukkan bahwa proses penyaluran dana bantuan ekonomi produktif program PEMP kepada KMP belum optimal, karena prosesnya tidak berikan langsung (tunai) melainkan hanya dalam berita acara penyerahan. Hal ini mengindikasi masih akutnya patologi birokasi, apabila ada kaitannya dengan dana, maka birokrasi itu sulit untuk koperatif, equality, dan transparan. Keadaan ini telah membuka peluang kebocoran dan penyelewengan serta KKN, dan ini terbukti adanya mark up terhadap pengadaan barang dan bahan pendukung usaha yang dikembangkan KMP.

Dari uraian di atas dapatlah
disimpulkan bahwa pengambilan
keputusan yang berorientasi pada
perubahan pola sikap, tingkah laku dan
watak, haruslah sejauh mungkin
memperhatikan konteks, faktor eksogen
penting, tetapi harus diselaraskan dan
memperhatikan suara-suara kelompok
target sasaran. Jika tidak, maka kegagalan-

kegagalan program tetap saja tidak terhindarkan.

\section{Penguatan Organisasi Sosial Ekonomi Masyarakat}

Sehubungan dengan pelaksanaan Program PEMP 2002 di Kecamatan Batudaa Pantai, telah dibentuk Lembaga Ekonomi Pemberdayaan Pesisir Mikro Mitra Mina (LEPP-M3) yang diberi nama PAYULIMO (Panca Sila). Melihat fungsinya strategis maka LEPP-M3 PAYULIMO secara kelembagaan haruslah didukung oleh tenaga tenaga profesional dan berpengalaman.

Dari data yang didapat melalui daftar pertanyaan yang diberikan kepada 40 responden atau $100 \%$. Hal ini menunjukkan bahwa masyarakat sangat mengharapkan berdirinya lembaga ekonomi semacam LEPP-M3 Poyulimo, karena selama ini kehadiran lembaga resmi pemberi modal usaha belum ada. Namun karena lembaga ini terletak di ibukota kabupaten yang jaraknya cukup jauh, maka kehadirannya kurang dirasakan dan tidak lancarnya hubungan antara KMP dengan LEPP-M3. Padahal kerjasama kedua lembaga sangat menentukan keberlanjutan program PEMP.

Mengenai peranan LEPP-M3 dalam rangka mengawal program PEMP, hasil kesimpulan wawancara dengan beberapa anggota KMP mereka mengatakan kurang merasakan fungsi lembaga ini. Mereka hanya beberapa kali saja, berhubungan dengan LEPP-M3. Pengurus dan anggotanya, kelompok tidak mengetahui persis jumlah dan orangnya.

Berdasarkan beberapa data yang ada, disimpulkan bahwa penguatan organisasi sosial ekonomi masyarakat kurang efektif disebabkan karena LEPP-M3 sulit diakses oleh KMP, dan tidak kapable baik 
mengenai organisasi, pengurus, maupun pengalaman dalam mengelola keuangan.

\section{Pendampingan Kelompok Masyarakat Pemanfaat}

Hasil temuan di lapangan, dari 40 responden untuk semua kategori pertanyaan mengenai kehadiran tenaga pendamping, frekuensi pendampingan, dan hubungan antara KMP dengan pendamping, semua atau $100 \%$ memberikan jawaban tidak pernah mengetahui kehadiran, tidak pernah ada pendampingan, dan sehingga hubungan antara KMP tidak pernah berkangsung. Data ini menunjukkan bahwa kehadiran tenaga pendamping tidak pernah ketahui oleh KMP yang didampingi, karena tenaga pendamping tidak pernah melakukan pertemuan sehingga otomatis hubungan antara mereka dengan KMP tidak dapat berlangsung sebagaimana diharapkan.

Para tenaga pendamping tidak didukung oleh pemahaman yang kuat akan karakteristik masyarakat pesisir serta latar belakang pendidikan yang kurang memadai, baik menyangkut juklak dan juknis, maupun pemdampingan itu sendiri. Hal ini berdampak kurang optimalnya pendampingan kelompok masyarakat pemanfaat.

Selain itu, realita dilapangan menunjukkan bahwa tenaga pendamping hanya bekerja sesuai proyek, lebih banyak berada di luar lokasi kelompok sasaran sehingga hasilnya kurang mengembirakan. Keadaan ini menyebabkan masyarakat tidak mengalami kemajuan kualitas hidup karena mereka tidak dapat memanfaatkan hasil jerihnya dari melaut.

Berdasarkan data di atas, dapatlah disimpulkan, bahwa pendampingan tidak berjalan sebagaimana yang diinginkan program. Penyebabnya, antara lain, pendampingan bekerja menggunakan logika proyek, tidak menetap di lokasi kelompok sasaran, serta tenaga pendamping tidak memiliki kemampuan baik segi pengetahuan pendampingan maupun dari segi perikanan dan kelautan.

\section{PENUTUP}

\section{Simpulan}

Mekanisme pemilihan KMP belumlah memberi ruang partisipasi dalam pengambilan keputusan dan pemberdayaan masyarakat miskin, juga tidak memberikan peran yang strategis bagi swasta dan berbagai pihak dalam mengatasi masalah kemiskinan yang mereka hadapi; Mekanisme pencairan dan pengelolaan dana kurang efektif, tidak transparan, artinya KMP belum diberi kesempatan berpartispasi mengelola dan mendayagunakan dana bantuan secara langsung, keadaan ini memberi peluang kebocoran dan penyelewengan dana program, dan masih mengikuti logika proyek; Penguatan organisasi sosial ekonomi masyarakat belum efektif, karena pengurus LEPP-M3 yang kurang kapabilitasnya, baik dalam mengelola organisasi sendiri maupun dalam membina KMP dan lemahnya peranserta masyarakat dalam mengakses LEPP-M3 dan lembaga terkait lainya; Proses Pendampingan kurang optimal, hal ini disebabkan karena sarana dan prasarana terutama sarana transportasi tidak memadai untuk menuju lokasi sasaran, tenaga pendamping tidak mempunyai kapabilitas dalam pendampingan maupun bidang yang akan didampingi, serta kurangnya intensif yang diterima.

\section{Saran}

Sebaiknya mekanisme pemilihan KMP memberi ruang partisipasi masyarakat dalam pengambilan keputusan 
dan pemberdayaan masyarakat miskin, serta memberikan peran yang strategis bagi stakeholders dalam mengatasi masalah kemiskinan khususnya masyarakat pesisir; Sebaiknya mekanisme pencairan dan pengelolaan dana dilakukan secara transparan, KMP diberi kesempatan berpartispasi mengelola dan mendayagunakan dana bantuan secara langsung ; Sebaiknya pemilihan pengurus LEPP-M3 dilakukan secara selektif untuk menghasilkan pengurus yang memiliki kapabilitas, sehingga mampu mengelola organisasi dan mampu melakukan pembinaan pada KMP ; Sebaiknya tenaga pendamping diseleksi secara khusus sesuai karakteristik lokasi dampingan, sehingga dapat melakukan pendampingan secara optimal dan proses pendampingan seyogyanya dilakukan secara purna waktu.

\section{DAFTAR PUSTAKA}

Niode, Alim S. 2003. Abad Besar Gorontalo. Gorontalo : Presnas Publi shing.

BPS Kabupaten Gorontalo. 2003. Kecamatan Batudaa Pantai Dalam Angka Tahun 2003.

Departemen Perikanan dan Kelautan, 2002. Pedoman Umum

Pemberdayaan Ekonomi Masyarakat Pesisir (PEMP). Departemen Perikanan dan Kelautan. Jakarta.

Imawan, Riswandha, 2004. Metodologi Penelitian Ilmu Politik. Yogyakarta : Program Ilmu Politik, Konsentrasi Politik Lokal dan Otonomi Daerah, UGM.

Langbein, Laura Irwin. 1980. Discovering Whethe Programs work : A Giude to

Statistical Methods for Program Evaluation. London : Scott, Foresman and Company.
LEPP-M3 Payulimo. 2002. Laporan Tahunan Lembaga Ekonomi Pengembangan Pesisir Mikro Mitra Mina (LEPP-M3). LEPP-M3 Payulimo. Limboto. Gorontalo.

Sumodiningrat, Gunawan, 2010. Pemberda yaan Masyarakat \& JPS, Jakarta : Gramedia Pustaka Utama,

Thoha, Miftah, 2007. Perilaku Organisasi, Konsep Dasar dan Aplikasinya. Jakarta: Raja Grafindo Persada

Usman, Sunyoto, 2004. Pembangunan dan Pemnerdayaan Masyarakat. Yogyakarta : Pustaka Pelajar 